\title{
A prospective comparative study of functional outcome in patients treated with interlocking nailing and dynamic compression plating for fracture shaft of humerus in adults
}

\author{
Prashant Bhutani*, Nikhil Gupta, Rahul D. Pujara
}

Department of Orthopaedics Surgery, Ruby Hall clinic, Pune, Maharashtra, India

Received: 14 May 2021

Revised: 10 June 2021

Accepted: 11 June 2021

\author{
*Correspondence: \\ Dr. Prashant Bhutani, \\ E-mail: prashant.bhutani3@gmail.com
}

Copyright: () the author(s), publisher and licensee Medip Academy. This is an open-access article distributed under the terms of the Creative Commons Attribution Non-Commercial License, which permits unrestricted non-commercial use, distribution, and reproduction in any medium, provided the original work is properly cited.

\begin{abstract}
Background: Aim of the study was to compare the functional outcome in patients with fracture shaft of the humerus treated with dynamic compression plating (DCP) and those treated with intramedullary interlocking nailing.

Methods: Of 44 patients with humeral shaft fracture were included in this study and were divided in the following two groups of 22 patients: Group A: Patients treated with DCP by triceps splitting approach and group B: Patients treated with standard intramedullary interlocking nailing. All patients were followed up at 6 weeks, 3 months and 6 months post operatively. Functional outcome was assessed using Rodriguez-Merchan criteria on follow up at 6 months post op. Results: The mean age of patients in group A was $39.05 \pm 13.13$ years and group B was $38.73 \pm 12.95$ years. According to Rodriguez-Merchan criteria, $8(36.4 \%)$ and $12(54.6 \%)$ patients in group A had excellent and good functional outcome respectively and $4(18.2 \%)$ and $10(45.4 \%)$ patients in group B had excellent and good functional outcome respectively.
\end{abstract}

Conclusions: DCP offers better functional outcome than interlocking nailing.

Keywords: Humeral shaft fractures, Rodriguez-Merchan criteria, DCP, Intramedullary interlocking nail

\section{INTRODUCTION}

Humeral shaft fractures account for 1 to $3 \%$ of all fractures in adults and for $20 \%$ of all humeral fractures. ${ }^{1}$ These fractures have an annual incidence from 13 to 14.5 per 100,000 people. Non-operative treatment is still the standard treatment for isolated humeral shaft fractures although this method can present unsatisfactory results, such as, non-union and shoulder impairment. Surgical treatment is recommended for patients with neurovascular injuries, brachial plexus injuries, open fractures, for patients with multiple injuries, and for floating elbow and unsatisfactory reductions. ${ }^{2-4}$ Arbeitsgemeinschaft für osteosynthesefragen (AO)-orthopaedic trauma association (OTA) type A fractures, proximal third oblique fractures and distal third shaft fractures. Surgical options for treatment of humeral shaft fractures include open reduction and internal fixation with a compression plate, intramedullary nail osteosynthesis and minimally invasive plate osteosynthesis. Open reduction and internal fixation (ORIF) with plates and screws continues to be considered the gold standard for surgical treatment. Plate fixation permits direct visualization, anatomic decrease, and rigid fracture fixation of the fracture and facilitates the identification exploration, and protection of the radial nerve. It is associated with a high union rate, low complication rate, and rapid return to function. It provides satisfactory results but requires extensive soft tissue dissection, and meticulous radial nerve protection. The plate may fail in osteoporotic bone. ${ }^{5,6}$ The theoretical advantage of intramedullary nailing included less invasive surgery, an undisturbed fracture hematoma and reaming can yield auto graft material, permits preservation of periosteal blood supply and limits disruption of fracture 
biology. ${ }^{7,8}$ The conflict between the need for absolute anatomical reduction and, at the same time, the desire for soft tissue preservation has been going on for a long time. Precise reduction and absolute stable fixation have its biological price. The current study was done to compare the functional outcome in patients with fracture shaft of the humerus treated with dynamic compression plating and those treated with intramedullary interlocking nailing.

\section{METHODS}

This study is a prospective comparative study. The patients who underwent surgery for humerus shaft fractures in the department of orthopaedics of Ruby Hall clinic, Pune, during the period of October 2018 to June 2020 were considered as study participants.

A total of 44 patients were included in this study. The patients were divided in the following two groups of 22 patients: Group A: Patients treated with dynamic compression plating (DCP) by triceps splitting approach and Group B: Patients treated with standard intramedullary interlocking nailing.

All patients were advised postoperative shoulder and elbow exercises on 3 weeks and radiographs were taken at regular intervals 6 weeks, 3 months and 6 months during follow up. At every follow up clinical examination was done to assess status of the surgical wound, pain, tenderness, range of motion of shoulder and elbow, stability of the fracture and clinical union. Roentgenograms were taken in AP and lateral views to look for signs of radiological union. The union is confirmed radiologically when plain X-ray showed bone trabeculae or cortical bone crossing fracture site on at least three surfaces on orthogonal radiograms. The time taken for clinical and radiological union was noted. RodriguezMerchan criteria were used to compare the postoperative results of IMIL Nail and plating procedure at follow up. ${ }^{9}$ Patients were assessed prospectively at period of 6 weeks, 3 months and 6 months. Functional outcome will be assessed at 6 months follow up.

A statistical significance among the study groups is assessed with the help of Fisher test, student ' $t$ ' test and Chi square test. $\mathrm{P}<0.05$ is taken as significant. Appropriate statistical software, including but not restricted to MS excel, SPSS ver. 20 were used for statistical analysis

\section{Inclusion criteria}

Inclusion criteria included patients who had acute fractures of humeral shaft, patients aged above 18 years, fractures 2 $\mathrm{cm}$ below surgical neck and $3 \mathrm{~cm}$ above olecranon fossa, multiple injuries and angulation more than 15 degrees.

\section{Exclusion criteria}

Exclusion criteria for the study excluded patients who had open physis, age less than 18 years and fractures involving proximal $2 \mathrm{~cm}$ and distal $3 \mathrm{~cm}$ of the humeral diaphysis.

\section{RESULTS}

Demographic details shown in the Table 1.

Table 1: Demographic distribution of patients in group $\mathbf{A}$ and $\mathbf{B}$.

\begin{tabular}{|c|c|c|}
\hline Characteristics & $\begin{array}{l}\text { No. of patients } \\
\text { in group } \mathbf{A}\end{array}$ & $\begin{array}{l}\text { No. of patients } \\
\text { in group B }\end{array}$ \\
\hline \multicolumn{3}{|l|}{ Age (Years) } \\
\hline $21-30$ & 6 & 7 \\
\hline $31-40$ & 8 & 6 \\
\hline $41-50$ & 4 & 3 \\
\hline $51-60$ & 2 & 4 \\
\hline$>60$ & 2 & 2 \\
\hline \multicolumn{3}{|l|}{ Sex } \\
\hline Male/female & $14 / 8$ & $12 / 10$ \\
\hline \multicolumn{3}{|c|}{ Laterality of fracture } \\
\hline Right/left & $9 / 13$ & $8 / 14$ \\
\hline
\end{tabular}

Distribution of patients according to functional outcome according to Rodriguez-Merchan criteria, 8 (36.4\%) and $12(54.6 \%)$ patients in group A had excellent and good results respectively while $1(4.5 \%)$ patient each had fair and poor results. $4(18.2 \%)$ and $10(45.4 \%)$ patients in group B had excellent and good results respectively while $6(27.3 \%)$ and $2(9.1 \%)$ patients had fair and poor results respectively (Table 2). There was significant improvement in group A compared to B as per Chi-square test $(\mathrm{p}>0.05)$.

Table 2: Distribution of patients according to functional outcome (Rodriguez-Merchan criteria).

\begin{tabular}{|c|c|c|c|c|c|c|c|c|}
\hline \multirow{3}{*}{ ROM } & \multicolumn{4}{|c|}{ Shoulder ROM } & \multicolumn{4}{|c|}{ Elbow ROM } \\
\hline & \multicolumn{2}{|c|}{ Group A } & \multicolumn{2}{|c|}{ Group B } & \multicolumn{2}{|c|}{ Group A } & \multicolumn{2}{|c|}{ Group B } \\
\hline & No. & $\%$ & No. & $\%$ & No. & $\%$ & No. & $\%$ \\
\hline Excellent & 17 & 77.3 & 12 & 54.5 & 17 & 77.3 & 20 & 90.9 \\
\hline Good & 5 & 22.7 & 6 & 27.3 & 5 & 22.7 & 2 & 9.1 \\
\hline Fair & 0 & - & 4 & 18.2 & 0 & - & 0 & - \\
\hline Poor & 0 & - & 0 & - & 0 & - & 0 & - \\
\hline Total & 22 & 100 & 22 & 100 & 22 & 100 & 22 & 100 \\
\hline
\end{tabular}


Table 3: Shoulder ROM and Elbow ROM results of Rodriguez-Merchan criteria in group $A$ and $B$.

\begin{tabular}{|c|c|c|c|c|c|}
\hline \multirow{2}{*}{$\begin{array}{l}\text { Rodriguez } \\
\text { Merchan } \\
\text { criteria }\end{array}$} & \multicolumn{2}{|c|}{ Group A } & \multicolumn{2}{|c|}{ Group B } & \multirow[b]{2}{*}{ P value } \\
\hline & No. & $\%$ & No. & $\%$ & \\
\hline Excellent & 8 & 36.4 & 4 & 18.2 & $<0.05$ \\
\hline Good & 12 & 54.6 & 10 & 45.4 & $<0.05$ \\
\hline Fair & 1 & 4.5 & 6 & 27.3 & $<0.05$ \\
\hline Poor & 1 & 4.5 & 2 & 9.1 & $<0.05$ \\
\hline Total & 22 & 100 & 22 & 100 & \\
\hline
\end{tabular}

The range of movement of shoulder joint and elbow function was excellent in $17(77.3 \%)$ patients and good in $5(22.7 \%)$ patients of group A. The range of movement of shoulder joint was excellent and good in $18(81.8 \%)$ patients and fair in $4(18.2 \%)$ patients of group B. The elbow function was excellent in $20(90.9 \%)$ patients and good recovery was found in $2(9.1 \%)$ patients of group B (Table 3).

\section{DISCUSSION}

There are several methods of operative intervention for fracture shaft of humerus, the internal fixation methods can be plating and interlocking intramedullary nailing. Plating is preferred option where radial nerve exploration is contemplated and interlocking nailing in communited, segmental and pathological fractures in plating technique an extensive surgical approach is required for open reduction of fractures. ${ }^{4,10}$ Intra-medullary nailing method provides with the advantage of biological fracture healing such as minimal handling of soft tissue, preservation of fracture hematoma, and stripping of periosteum, lesser operative time and decreased blood loss, thus making it much preferable choice of treatment in these injured patients. ${ }^{11,12}$ However, nailing has certain disadvantages like insertion site morbidity such as impairment of shoulder movements, impingement at acromion and the incursion of the rotator cuff..$^{11-13}$

Naveen et al study observed among 34 patients, 11 had excellent results, 9 had good results, 8 had fair and 6 had poor results. Among the 11 patients with excellent results, 6 patients were treated by dynamic compression plating and 5 were treated by interlocking nailing. Among the 9 patients with good results, 5 patients were treated by dynamic compression plating and 4 were treated by interlocking nailing. ${ }^{14}$

Kumar et al prospective study reported functional activity at elbow as assessed by American shoulder and elbow surgeon score and constant and Murley score for shoulder function activity score was $66.66 \%$ in plating group and 60 of interlocking group showed excellent result. Good result shown by $26.66 \%$ of plating, $33.33 \%$ of nailing group. ${ }^{15}$

In present study, according to Rodriguez-Merchan criteria, out of 22 patients in each group, 8 (36.4\%) and 12 (54.6\%) patients in group A had excellent and good results respectively while $1(4.5 \%)$ patient each had fair and poor results. $4(18.2 \%)$ and $10(45.4 \%)$ patients in group B had excellent and good results respectively while 6 (27.3\%) and $2(9.1 \%)$ patients had fair and poor results respectively. There was significant improvement in Group A compared to group B as per Chi-square test ( $p>0.05)$.

\section{CONCLUSION}

Internal fixation with various fixation devices allows early mobilization and good functional recovery. Operative treatment results with dynamic compression plate and interlocking nail were comparable in many senses with some pits and fall in each group. But considering the functional outcome and rate of complications, dynamic compression plating offers better result than interlocking nailing.

\section{Funding: No funding sources}

Conflict of interest: None declared

Ethical approval: The study was approved by the institutional ethics committee

\section{REFERENCES}

1. Emmett JE, Breck LW. A review and analysis of 11,000 fractures seen in a private practice of orthopaedic surgery, 1937-1956. J Bone Joint Surg Am. 1958;40-A:1169-75.

2. Amillo S, Barrios RH, Martinez-Peric R. Surgical treatment of the radial nerve lesions associated with fractures of the humerus. $\mathrm{J}$ Orthop Trauma. 1993;7:211-5.

3. Foster RJ, Swiontkowski MF, Bach AW. Radial nerve palsy caused by open humeral shaft fractures. J Hand Surg. 1993;18:121-4.

4. Pollock FH, Drake D, Bovill EG. Treatment of radial neuropathy associated with fractures of the humerus. J Bone Joint Surg Am. 1981;63(2):239-43.

5. Singisetti K, Ambedkar M. Nailing versus plating in humerus shaft fractures: A prospective comparative study. Int Orthop. 2010;34:571-6.

6. Hwang YS, Kim KY, Kim HC. Polarus Intramedullary Nail for Proximal Humeral and Humeral Shaft Fractures in Elderly Patients with Osteoporosis. J Korean Fract Soc. 2013;26:14.

7. Crolla RMPH, De Vries LS, Clevers GJ. Locked intramedullary nailing of humeral fractures. Injury. 1993;24:403-6.

8. Habernek H, Orthner E. A locking nail for fractures of the humerus. J Bone Joint Surg Br. 1991;73:651-3.

9. Rodríguez-Merchán EC. Compression plating versus hackethal nailing in closed humeral shaft fractures failing nonoperative reduction. J Orthop Trauma. 1995;9(3):194-7.

10. McCormack RG, Brien D, Buckley RE. Fixation of fractures of the shaft of the humerus by dynamic compression plate or intramedullary nail: A prospective randomized trial. J Bone Joint Surg Br. 2000;82(3):336-9. 
11. Hall RF Jr, Pankovich AM. Ender nailing of acute fractures of the humerus. A study of closed fixation by intramedullary nails without reaming. J Bone Joint Surg Am. 1987;69(4):558-67.

12. Watanabe RS. Intramedullary fixation of complicated fractures of the humeral shaft. Clin Orthop rel res. 1993;292:255-63.

13. Agarwal A, Chandra A, Jaipal U. A panorama of radial nerve pathologies- an imaging diagnosis: a step ahead. Insights Imaging. 2018;9(6):1021-34.

14. Naveen PR, Chaitanya PR. Comparative study between the dynamic compression plating (DCP) and the intramedullary interlocking nailing in diaphyseal fractures of the humerus in adults. J Evolution Med Dental Sci. 2013;2(45):8704-12.

15. Kumar R, Singh P, Chaudhary LJ. Humeral shaft fracture management, a prospective study of nailing or plating. J Clin Orthop Trauma. 2012;3(1):37-42.

Cite this article as: Bhutani P, Gupta N, Pujara RD. A prospective comparative study of functional outcome in patients treated with interlocking nailing and dynamic compression plating for fracture shaft of humerus in adults. Int J Res Orthop 2021;7:7869. 